\title{
Collaboration of the Delivery Passport Service Innovation Program at the Makassar City Immigration Office Class I
}

\author{
$\operatorname{Rudi}^{1}$, Armin $^{1}$, Hasniati $^{1}$, Muhammad Rusdi ${ }^{1}$ \\ *Corresonding Email: rudiamru@gmail.com \\ ${ }^{1}$ Public Administration, Faculty of Social and Political Sciences, Hasanuddin University, \\ Indonesia
}

\begin{abstract}
Class I Immigration Makassar City is one of the institutions under the auspices of the Ministry of Law and Human Rights of the Republic of Indonesia which has made many innovations in terms of passport services. One of them is passport delivery innovation in collaboration with PT. Pos Makassar Branch in serving passport delivery to the applicant's address. The collaboration between Class I Immigration Makassar City and PT. Pos Makassar branch aims to provide convenience for the public in obtaining passports through the delivery service of PT. Pos Makassar Branch. This research uses a qualitative descriptive approach with data collection techniques carried out through interviews, observations and documentation of informants who are directly involved in passport delivery services. The data were analyzed through the stages of data reduction, data presentation, and drawing conclusions and verification. In the collaboration process, it is seen from the aspect of managing aims; compromise, communication, democracy and equity; power and trust and determination, commitment and stamina. This study shows that each actor has the same goal, the establishment of open communication that can foster trust between actors and a strong commitment in improving passport delivery services to the public.
\end{abstract}

Keywords: Collaboration, Innovation, Service

Received: April 16, 2021

Revised: May 12, 2021

Accepted: May 23, 2021

\section{Introduction}

The government is required to always adjust to what is needed by the community, one of which is the need for decent public services. The adjustment is an effort to respond to global developments that occur in the internal and external environment in the administration of government. This is because the development of an increasingly global environment demands the roles of government agencies that can accommodate all interests within the framework of democracy. Various collaborations or collaborations between stakeholders in the administration of government are also carried out as an effort and government response in handling public problems. (Haryono, 2012)

Collaboration is defined as a form of cooperation, interaction, compromise of several related elements, both individuals, institutions or parties involved directly and indirectly who receive the consequences and benefits. The complexity of public problems and the demands of society to get the convenience of services, like it or not, the government must respond to the public interest. The government as a service provider experiences many limited resources (human, technology, information, finance). To complement these limitations, collaboration is an alternative for the government to answer the demands of the community, especially in realizing innovative service quality. 
Effectiveness in the implementation of public services, organizations have an interest in building inter-organizational relationships due to limited control/ownership of resources. This relationship is to complement each other (mutualist symbiosis) in order to achieve common goals or the goals of each organization concerned. The dependence of resources on other organizations needs to be managed properly through: first, that they must influence other organizations in order to obtain resources; second, they must respond to the needs and demands of other organizations in their environment. The level of dependence of an organization on certain resources is a function of two factors, namely: first, how important these resources are for the survival of the organization; second, the extent to which these resources are controlled by other organizations. In relation to collaboration, resource dependence theory asserts that the success of an organization is highly dependent on the quality of the relationships they have with other organizations. (Jones 2004 quoted by Syamsu, 2014).

The collaboration between the Class I Immigration Office of Makassar City and PT Pos Indonesia Makassar Branch is a tangible manifestation of the slogan of one stop services in improving service quality by providing passport delivery service facilities to the applicant's home. One of the breakthroughs and proof of the seriousness of the Makassar City Immigration Office in improving public services and has proven to be successful in being named the 2 nd best Technical Implementation Unit in 2018 in innovative passport services within the scope of the Ministry of Law and Human Rights in the South Sulawesi Region. They are able to prove that the Makassar City immigration service is getting faster, transparent, efficient, and innovative. Where innovation is formed to change the mindset of employees from being served to serving, meaning that serving is an obligation for government officials.

The innovation of passport services at the Makassar City Immigration Office Class I cannot be separated from the participation of other organizations, such as PT Pos Indonesia Makassar Branch, which is a partner in service delivery. The limitations and dependence of resources owned in an organization or government agency for public services encourage the government to foster cooperative relationships between stakeholders with the main objective of supporting the realization of an effective, efficient and more transparent government administration process and can overcome problems that arise, either directly or indirectly. in the implementation of public services and have an impact on community satisfaction.

The collaboration process in passport delivery service innovation lies in the ability of the parties to formulate and institutionalize a common vision. If the actors and parties succeed in institutionalizing a common vision and formulating their respective strategies and activities, most of the problems that are often faced in collaboration will be overcome. The collaboration process proposed by Chris Huxham et al. (1996) uses the dimensions of the collaboration process, namely: (1) managing aims (achievement of goals); (2) compromise (compromise); (3) communication (communication); (4) democracy and equity; (5) power and trust and; (6) determination, commitment and stamina.

Based on the components and explanations of the collaboration theories mentioned above, it is considered capable of explaining the phenomena related to collaboration in the innovation of passport delivery services at the Makassar City Immigration Office with PT. Pos Makassar Branch. This study aims to analyze the collaboration process between Makassar City Immigration and PT. Pos Indonesia in innovation of passport delivery services at the Makassar City Immigration Office. The success of collaboration is largely determined by how the collaboration process is fostered by each party in determining common goals, then collaboration between stakeholders creates innovations that are able to meet community needs for services provided by the government 


\section{Methods}

This study uses a qualitative deductive approach. This research focuses on. collaboration process, which means that in this study explains how the series of collaboration processes that occur between the Makassar City Immigration Office Class I and PT Pos Makassar branch in passport delivery services. The location of this research was carried out at the Makassar City Immigration Office Class I. The research data was obtained from primary sources, namely field research by conducting interviews with several informants, namely the Head of Immigration Class I Makassar City, Head of the Makassar Post Office Branch, Head of Administration for the Makassar Class I Immigration Office. , Head of Traffic and Immigration Office Class I Makassar, Passport Service Counter Officer, employee of PT Pos Passport delivery service. As well as other informants, are the public as users of passport services. Secondary data is obtained from documentation by studying various cooperation agreement $(\mathrm{MoU})$ documents and various other relevant documents. Observation is used to complete and review the results of interviews given by the resource persons and may not be comprehensive or not able to describe all the expected situations.

The data analysis used in this study is the Analysis Interactive Model from Miles et al. (2014). Analysis of statements based on interviews from informants. Data analysis goes through stages, namely: data condensation (data condensation), data presentation (data display), and drawing conclusions or verification (conclusion drawing and verification). The research results are presented in a narrative manner.

\section{Results and Discussion}

The collaboration process in the innovation of passport delivery services at the Makassar City Immigration Office Class I, in the view of Huxham et al. (1996) which is put forward into six dimensions of the collaboration process between organizations, namely (1) Managing aims ( management objectives) (2) Compromise (3) Communication (4) Democracy and Equality (5) Power and Trust (6) Determination, Commitment and Stamina , commitment and endurance).

\section{Managing Aims}

The purpose of collaboration management, where this dimension focuses on a question about the reasons for the aspects and goals so that collaboration occurs. In this case an explanation of the reasons and objectives of the Makassar City Immigration Class I with PT. Pos Makassar Branch in providing passport delivery services to the public. Based on passport applicant data at the Makassar City Immigration Class I Office, in the 2016 - 2019 period, passport applicants have increased. The increase in passport applications was seen from 2016 the number of passports issued by the Makassar City Immigration Class I amounted to 61,838 passports, in 2017 there were 63,947 passports and in 2018 there were 62,518 passports, and in 2019 there were 65,630 passports.

Along with the increasing number of passport applications, the Directorate General of Immigration through the Makassar City Immigration Office Class I to provide maximum service with an integrated service model is considered to be able to overcome various existing problems, so that innovative programs are born, such as integrated passport services (one-stop service). Passport service with a one stop service system is an improvement in the service system that changes the convoluted service system and is expected to be more profitable in terms of time for passport applicants and reduce interactions between applicants and officers. This integrated passport service aims to simplify the service flow from previously very complicated procedures, many acts of brokering services, a long time, so this innovative 
immigration program can provide easy access for every applicant in the form of simplifying services both offline and in online form.

In 2016 the Directorate General (Ditjen) of Immigration again launched a new program to improve the previous service with delivery services, where this program was presented to relieve people's fatigue because they had to come when picking up passports. Then this innovation program was responded to by Immigration Class I Makassar City to provide services with a delivery service system in collaboration with PT. Pos Indonesia Makassar Branch to facilitate the public in passport services.

Passport delivery service is presented to relieve people's fatigue when taking passports. Applicants no longer need to be present at the Makassar City Immigration Office Class I to queue up for passport collection, with the existence of a passport delivery service to the applicant's home address, it can reduce the queue density at the Makassar Class I Immigration Office. Besides the innovation program for passport delivery services, it aims to make it easier for people to get passports, it can also save time so that applicants no longer need to queue at the passport collection counter.

Observing the flow of passport service procedures at the Class I Immigration Office of Makassar City which is systematically the basis that there are efforts to improve and improve good service to the community. The hope of a significant change in the realm of the flow of this service procedure can automatically be felt by the community/passport applicant. The importance of realizing maximum service as regulated in law number 25 of 2009 concerning public services and is increasingly being realized by various parties in providing services such as the Class I Immigration Office of Makassar City.

The main goal in this passport delivery service is how to meet the needs of the community in order to obtain the desired and satisfying service. Therefore, the government must provide space for non-government actors to participate optimally in government activities so as to allow synergy between government and non-government actors and institutions to be able to collaborate to provide public services to the community.

\section{Compromise}

A mutual agreement that was built by the Makassar City Immigration Class I with PT Pos Makassar Branch to provide convenience to the public in passport services at the Makassar Class I Immigration Office. The dimension of compromise in the delivery of passport services to the public is interpreted as an effort by the Class I Immigration of Makassar City and PT. Pos Makassar Branch in resolving differences of opinion that developed during cooperation in the delivery of passport service to the public. Problems that may occur are related to authority, procedures for sending passports to the public, can be resolved in a deliberation mechanism, so that the division of tasks and obligations of each actor does not have juridical legitimacy as a formal legal basis for collaboration.

The collaboration built by the Makassar City Immigration Class I with PT. Pos Makassar Branch is based on a work contract as outlined in a cooperation agreement. There is a mutual compromise for the interests of Class I Immigration Makassar City and PT. Pos Makassar Branch in facilitating passport delivery services to the public.

The agreement in this collaboration is contained in the cooperation agreement between Immigration and PT. Pos Makassar Branch Number: 518-MS/REGIONAL-10/2017 - Number: W 23 IMI.FB.HH 05.05-2177 regarding passport delivery services with the intent and purpose of providing convenience, speed and security of service to the public in sending passports. The 
agreement regulates the rights and obligations of the parties and jointly agrees to socialize the passport delivery innovation program to the public.

Based on the results of the interview, it was revealed that in resolving differences or problems in the implementation of the passport delivery service program, both parties prioritized a compromise approach with open communication through deliberation and consensus methods. In every meeting the actors have a strong awareness to find the right formula in establishing a relationship without anyone being harmed. As partners who cooperate in the implementation of public services, the agreement of all parties must be regulated in the form of an agreement as a guide for collaborating.

With the deliberation approach in solving problems in passport delivery services at the Makassar City Immigration Office Class I, it is a good reflection of the cooperative relationship between Makassar City Immigration Class I and PT. Pos Makassar Branch. Compromise is the best and elegant way in resolving various differences of interest, by maintaining a balance of rights and obligations, cultivating a fair attitude and getting used to deliberation and consensus in decision making and prioritizing common interests in realizing good service to the community.

\section{Communication}

Communication is one of the important factors in the implementation of public services (Hermana \& Silfianti, 2011; Akula et al., 2014). Class I Immigration Makassar City realizes that in making decisions, it is very necessary to have good communication with all elements. Open communication at every stage in the service is important to identify the problems faced in the passport delivery service together. All parties have the same access to information regarding the needs in the Implementation of passport delivery services. The problems encountered can be communicated properly and openly through regular evaluation meetings conducted by the Immigration Class I with PT.

Pos Makassarsar Branch. The communication role of each actor is very decisive in the success of the passport. delivery service program at the Makasar City Immigration Office Class I. Immigration OfficeClass I. Makassasar and PT. Pos Makassar. MakAssar Branch Post are able to build a close relationship in the cooperation and communication in the process of good communication.

In managing this collaboration, the communication role. of eachActor is key to the success. of the program in passport delivery. services. Immigration Class I. Makassar City issues 65,630 passports in 2019. Only 1.23 percent of the 62,518 passports issued were delivered to the applicant's address. The percentage of passport delivery service users in 2018 was only 1.23 percent. Effective communication is needed in improving passport delivery services, says PT. Pos chief. The success of the delivery service at the Immigration Office is largely determined by the communication role of the parties in disseminating to the public or passport applicants to use the services of PT. Pos.

\section{Democracy and Eguality}

Democracy and equality in the implementation of passport delivery services at the Makassar City Immigration Office is focused on how the decision-making process is, who is involved in the collaboration process and the form of responsibility of each actor who has autonomous authority to interact through negotiations both formally and informally. informal. Based on the results of research on the implementation of passport delivery services, which are service 
program innovations carried out jointly with PT. Pos Makassar Branch in creating rules and structures that regulate relationships and how to act on passport delivery services.

In collaboration with passport delivery services, Immigration is the provider of passport services to the public, while PT. Pos itself serves as a passport delivery service to applicants/community.

Collaboration in the passport delivery service which is the main focus is how the decisionmaking process is. Decision-making in every formal and informal meeting prioritizes democratic principles. The principle of democracy is an important value and is realized through the involvement of each actor in every decision making. These democratic values include aspects of equality and openness.

The aspect of openness in the passport delivery service reflects the decisions taken in accordance with the opinions, desires and needs of the community as users of the passport delivery service. This democratic decision-making can have implications for increasing trust in each actor, so that the responsibility and role of each actor in the implementation of this passport delivery service program can be realized in a formal form with a cooperation agreement.

The form of accountability in passport delivery services, both Makassar City Immigration and Makassar branch PT. Pos at any time jointly monitor and evaluate the progress of the passport delivery service program. Monitoring is intended to avoid technical and procedural errors in the implementation of the passport delivery service program to the public/applicants. The Immigration Department also always evaluates the activities of the PT. Posts in the Immigration work area with the aim of seeing how effective the passport delivery service process is to the public.

With a common vision approach to serve the community, all decisions in the passport delivery service program at the Makassar City Immigration Office Class I are always built on the basis of mutual agreement. In addition, the actors who are directly involved as the person in charge of the passport delivery service program in the hope of being able to easily provide solutions to the obstacles in the passport delivery service at the Class I Immigration Office of Makassar City.

Based on the results of interviews, it shows that the involvement of the parties in solving problems related to passport delivery services is always prioritized by deliberation to achieve a common perception in running the passport delivery service program. The roles and responsibilities of actors in solving problems will certainly have an impact on the effectiveness of passport delivery services to the community.

\section{Power and Trust}

Building trust is an integral phase of dialogue or negotiation regarding the substance of a policy, so the success rate of collaboration will be greatly influenced by the building of trust. The dimension of trust is something that is important and fundamental in managing collaboration, because trust is a strength for actors to collaborate. Examining the passport delivery service program at the Makassar City Immigration Office Class I from the aspect of very large trust between the two actors.

It was revealed that in the implementation of passport delivery services at the Class I Immigration Office of Makassar City, both from the Immigration Office and from PT. Pos itself, they prioritized mutual trust between them, this was stated in a written agreement that regulated the duties and responsibilities of each party in collaborate. Where in the agreement 
the parties do not transfer or transfer rights and obligations to other parties in this passport delivery service program without written consent.

The existence of trust from each actor is a strength in the cooperative relationship between Immigration Class I Makassar City and PT. Pos Makassar Branch. Trust will help smooth the work, when the Immigration Class I Makassar City which has a cooperative relationship gives trust to PT. Makassar Branch Post to carry out duties and responsibilities in passport delivery services to the public.

Based on the information from the interviews, it was revealed that in the implementation of passport delivery services at the Class I Immigration Office of Makassar City, both from the Immigration and PT. Pos itself, they prioritized open dialogue to discuss the problems faced related to passport delivery services, so that these problems can be solved properly. With the openness of each actor in the collaboration process, it can provide strength and confidence in a cooperative relationship. Trust from each actor is a strength in the cooperative relationship between Immigration Class I Makassar City and PT. Makassar Branch Post.

Trust will help smooth the work, when the Immigration Class I Makassar City which has a cooperative relationship gives trust to PT. Post Makassar Branch to carry out their duties and responsibilities in passport delivery services to the public will certainly give a good value to their performance. This collaboration can only be built through a collaborative process that fosters trust, with the presence of trust in collaboration, it can enhance high-level relationships in carrying out the duties of each party.

\section{Determination, Commitmen and Stamina}

Collaboration between Makassar City Immigration Class I and PT. Pos. Post is to make it easier for the public to get a passport with a delivery service system to the applicant. The purpose of this collaboration is to provide convenience, speed and security of service to the community. The services provided by the government are continuously making improvements as evidence that the government's determination and commitment to serve the community well and does not hinder people's access to public services.

The collaboration provides business development opportunities for PT. pos. Post and Class I Immigration Makassarsar City to create quality passport services, according to the agreement. The agreement is to create service innovations that were simple, fast, easy to obtain and not complicated, says the government. The Indonesian government is committed to providing quality public services to the public, says Joo Sung-hyeong Lee.

The cooperation agreement is a guideline for the implementation of passport delivery services through the PT. Pos Makassara Branch network. Collaboration is not just working together or working together, but it contains a common vision or common goal. Collaboration can be done through a shared vision process so that the collaborating parties can know the duties and responsibilities. The existence of a common goal in collaboration can provide guidance in implementing the collaborative program, so that it can succeed in accordance with the objectives to be achieved. The commitment of the actors in collaboration is a key to improving the quality of public services. Therefore, firmness and strong determination in working together to serve the community is needed.

The government is always required to achieve maximum service effectively and efficiently, in the sense that the energy that has been spent by the government and the community in the service process will be significantly saved. With this passport delivery service, people who 
want to get public services only need to come to the Makassar City Immigration Office once, then all passport service matters will be resolved.

Referring to the dimension of managing aims in this collaboration process, as Huxham et al. (1996) say that there are three important things in the collaboration process, first is the existence of an explicit statement of the goals to be achieved, secondly there is an elaboration of interests. what each organization involved in a collaboration wants to achieve and the third is a description of the individual goals of each organization. From this explanation, there is a compatibility in the collaboration process of Makassar City Immigration Class I with PT. Pos Makassar branch in passport delivery services, where the two actors have a commitment to work together in creating passport services at the Makassar City Immigration Office class I.

This is in line with the opinion of Thomson et al. (2007) which says that collaboration is understood as a non-linear iterative process, meaning that if the organizations involved in collaboration can negotiate with the hope of joint action, then commit to initial action. In the concept of governance, it is explained that the state or government is no longer believed to be the only institution capable of carrying out services efficiently, economically and fairly. so that the governance paradigm views the importance of partnership and networking between stakeholders in the delivery of public services. Collaboration is not only carried out between the government and the private sector, but also between the government and the government. strengthening between government agencies can have an impact on improving service delivery to the community.

The agreement that is built in the passport delivery service is regulated through a cooperation agreement. The agreement or agreement can provide information about the obligations of each party in passport delivery service activities. So that each of the collaborating parties can easily control or supervise the implementation of these services. This view is as stated by Dwiyanto (2010) which explains that in collaboration, the government and the private sector have the same or equal position, therefore the work mechanism developed in collaboration is a functional work mechanism. This means that each party carries out activities based on the functions it develops in solving certain public problems in accordance with the mutually agreed division of labor.

Collaboration in the implementation of passport delivery services at the Class I Immigration Office of Makassar City is largely determined by teamwork in carrying out their duties. Immigration realizes that this passport delivery service can run according to what is expected if the mutually agreed agreement can be carried out properly. Intensive communication is very important in collaboration, communication can be done directly and indirectly to avoid conflicts between actors. In making decisions, the parties were given the freedom to express opinions related to the implementation. The results of the decisions that have been agreed are carried out according to their respective authorities which can benefit both parties.

The parties work together and in synergy carry out the work duties and responsibilities that have to be agreed upon in the agreement. The values of democracy and equality, which are the basis for building cooperation with PT. Pos Makassarsar are key to the success of the collaboration.

In accordance with this, Dwiyanto (2010) explains in detail that in collaborative cooperation there is the delivery of vision, goals, strategies, and activities between parties, each of them has the authority to make decisions independently and has the authority to manage their organization even though they subject to mutual agreement. Both parties build an agreement 
on a problem, create a solution to the problem, and promote shared values to produce a decision that benefits all parties.

Collaboration as a thought process in which the parties involved look at the different aspects of a problem and find solutions to these differences and the limitations of their views on what can be done. Collaboration can be interpreted as togetherness, cooperation, various tasks, equality and responsibility where the collaborating parties have a common goal, common perception, willingness to process and provide mutual benefits.

In decision-making, all parties are placed in the same position so that both have respect for each other. The Immigration Class I Makassar City gives trust to PT. Pos Makassar Branch to carry out duties and responsibilities. The openness of each actor in the collaboration process can provide strength and confidence in a cooperative relationship. Their strong commitment in providing passport delivery services is based on their intention and sincerity to serve the community, says Dr. Hijri.

The commitment of Class I Immigration of Makassarsar City and PT. Pos Makassar to provide the services to the community has implications for the success of the program, he says. The study was published in the journal of the International Journal of Public Policy and Social Development. It was published by the International Institute for Strategic Studies and Public Policy, a think-tank based in Washington, D.C., on June 20, 2013. The author also published a paper on the implementation of passport delivery service in the Philippines. It found that the Immigration Office of Makassesar City prioritized mutual trust between them, it was poured into a written agreement.

In accordance with the opinion of Ansell \& Gash (2008: 550-561 explaining in detail that commitment is a very important component in the collaboration process, where the collaboration process begins with a face-to-face dialogue process so that it can build mutual trust and commitment between actors in collaboration. Meanwhile, Huxham et al. (1996) explains that the collaboration process on the dimensions of determination, commitment and stamina is characterized as an unbalanced collaboration situation, meaning that one party is experienced and the other party is inexperienced so that the goals of collaboration are difficult to achieve. with the commitment of the actors who formulate their agenda for "matching" in the collaboration program Determination, commitment and stamina in collaboration are defined as the commitment and determination of the actors in determining the sustainability of a collaboration.

\section{Conclusion}

Based on the results of research in the field and the discussion that has been described previously, it can be concluded that the collaboration process between Class I Immigration Makassar City and PT. Makassar Branch Post in passport delivery services at the Class I Immigration Office of Makassar City is based on the aspect of a common goal to provide convenience, speed and security in passport delivery services to the public. Limited resources owned by Immigration class I Makassar city in the implementation of passport delivery services so that compromises and formal cooperation agreements with PT. Pos Makassar Branch to support facilities and infrastructure in passport delivery services are limited. Formally built collaboration is the main foundation for each actor to carry out his duties and responsibilities and is committed to realizing a common vision, mission and goals. Then open 
communication is important to be able to create trust between actors in order to create a common perception in solving problems in passport delivery services.

\section{References}

Akula, R. P., Narasimha, V. B., \& Chandrashekar, M. (2014). Technology implementation in public sectors units of Andhra Pradesh. International Journal of Advanced Computer Research, 4(2), 518.

Ansell, C. \& Alison G. 2007. Collaborative Governance In Theory And Practice. Journal Of Public Administration Research And Theory.,Published by Oxford University Press JPART 18 (4):543-571.

Dwiyanto, Agus. 2010. Manajemen Pelayanan Publik : Peduli, Inklusi, dan Kolaboratif. Universitas Gajah Mada Press, Yogyakarta.

Haryono, N. (2012) Jejaring untuk membangun Kolaborasi Sektor Publik. Jejaring Administrasi Publik Th IV. Number 1,January-Juni 2012

Hermana, B., \& Silfianti, W. (2011). Evaluating e-government implementation by local government: digital divide in internet based public services in Indonesia. International Journal of Business and Social Science, 2(3).

Huxham, Chris, and Siv Vangen. (2000) Leadership in the Shaping and Implementation of Collaboration Agendas: How Things Happen in a (Not Quite) Joined -Up World. Academy of Management Journal 43, 1159-75.

Miles, M.B, Huberman, A.M, dan Saldana, J. (2014) Qualitative Data Analisis, A Methods Sourcebook, Edition 3 USA: Sage Publications, translated by Tjetjep Rohindi Rohidi,UI-Press

Syamsu, S. (2014), Model Intergovernmental Management Dalam Program Pendidikan Gratis Di Provinsi Sulawesi Selatan. Doctoral Diseratation Program Ilmu Administrasi Publik Universitas Hasanuddin Makassar.

Thomson, Ann M. \& James L. Perry. (2007). Collaboration Processes: Inside the Black Box. Public Administration Review. Page20-32. 